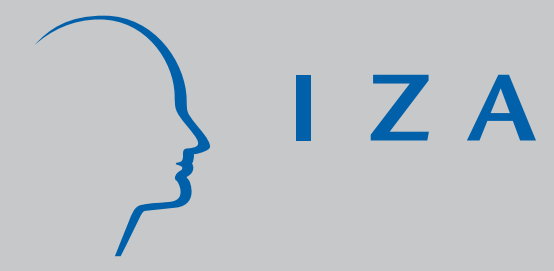

IZA DP No. 592

Testing Lazear's J ack-of-All-Trades View of Entrepreneurship with German Micro Data J oachim Wagner

October 2002 


\title{
Testing Lazear's Jack-of-All-Trades View of Entrepreneurship with German Micro Data
}

\author{
Joachim Wagner \\ University of Lueneburg, HWWA and IZA Bonn
}

Discussion Paper No. 592

October 2002

\author{
IZA \\ P.O. Box 7240 \\ D-53072 Bonn \\ Germany \\ Tel.: +49-228-3894-0 \\ Fax: +49-228-3894-210 \\ Email: iza@iza.org
}

This Discussion Paper is issued within the framework of IZA's research area The Future of Labor. Any opinions expressed here are those of the author(s) and not those of the institute. Research disseminated by IZA may include views on policy, but the institute itself takes no institutional policy positions.

The Institute for the Study of Labor (IZA) in Bonn is a local and virtual international research center and a place of communication between science, politics and business. IZA is an independent, nonprofit limited liability company (Gesellschaft mit beschränkter Haftung) supported by the Deutsche Post AG. The center is associated with the University of Bonn and offers a stimulating research environment through its research networks, research support, and visitors and doctoral programs. IZA engages in (i) original and internationally competitive research in all fields of labor economics, (ii) development of policy concepts, and (iii) dissemination of research results and concepts to the interested public. The current research program deals with (1) mobility and flexibility of labor, (2) internationalization of labor markets, (3) welfare state and labor market, (4) labor markets in transition countries, (5) the future of labor, (6) evaluation of labor market policies and projects and (7) general labor economics.

IZA Discussion Papers often represent preliminary work and are circulated to encourage discussion. Citation of such a paper should account for its provisional character. A revised version may be available on the IZA website (www.iza.org) or directly from the author. 
IZA Discussion Paper No. 592

October 2002

\section{ABSTRACT}

\section{Testing Lazear's Jack-of-All-Trades View of Entrepreneurship with German Micro Data*}

This paper tests the theory recently put forward by Edward Lazear that individuals with competence in many skills should have a higher probability of being self-employed than others. The empirical results for Germany support this jack-of-all-trades view.

JEL Classification: J23, R12

Keywords: entrepreneurship, jack-of-all-trades theory, Germany

Joachim Wagner

University of Lueneburg

Institute of Economics

D-21332 Lueneburg

Germany

Tel.: +49 4131-78-2330

Fax: +49 4131-78-2026

Email: wagner@uni-lueneburg.de

The data used in this study were kindly provided by the Zentralarchiv fuer Empirische Sozialforschung, Universitaet zu Koeln. I alone am responsible for all computations and interpretations of results. Financial support from the German Science Foundation under grant no. Wa 610/2-1/2 is gratefully acknowledged. 


\section{Motivation}

In a recent paper that has the potential of becoming a pivotal element in the field Edward Lazear (2002) proposed the jack-of-all-trades view of entrepreneurship. Based on a coherent model of the choice between self-employment and paid employment Lazear shows that having a background in a large number of different roles increases the probability of becoming an entrepreneur. The intuition behind this proposition is that entrepreneurs must have sufficient knowledge in a variety of areas to put together the many ingredients needed for survival and success in a business, while for paid employees it suffices and pays to be a specialist in the field demanded by the job taken. Lazear used a data set of Stanford alumni to test this prediction of his model and found it to hold - those with more varied experience have much higher probabilities of starting their own business.

Stanford alumni might not be representative for the millions of people facing the choice between self-employment and paid employment. This note contributes to the entrepreneurship literature by empirically testing Lazear's jack-of-all-trades hypothesis using a large recent representative sample of the German working population. Section 2 gives information on the data used and descriptive statistics, section 3 discusses the results from the econometric investigation, and section 4 concludes.

\section{Data and descriptive statistics}

The empirical investigation is based on a representative 0.1 percent sample of the working population in Germany conducted between October 1998 and March $1999 .{ }^{1}$

1 The data from the study "Erwerb und Verwertung beruflicher Qualifikationen von Erwerbstaetigen - BIBB / IAB - Strukturerhebung 1998/1999" are available for scientific (non-commercial) research for a nominal fee from the Zentralarchiv fuer Empirische Sozialforschung (ZA) at the University of Cologne, Germany. The archive 
We restrict our analysis to all individuals between 18 years (the legal minimum age for running your own firm) and 65 years (the mandated age of retirement for paid employees). Among others, the survey asks whether the interviewee is self-employed. In our sample of 33.633 individuals the share of self-employed is 9.36 percent - a figure well in line with evidence from the regular Mikrozensus, an official one-percent sample of the German population.

Being self-employed or not is at the heart of our empirical investigation. Closely following Lazear (2002) we include sex, nationality and age as control variables, and we focus on the influence of knowledge in a variety of areas on the probability of becoming an entrepreneur. The breadth of experience of an interviewee is proxied by two variables. One variable is the number of different kinds of professional training after completing school (e.g., apprenticeships, degrees as a master craftsman, university degrees). Interviewees reported between zero and six kinds of professional training, although only a minor fraction had five $(\mathrm{N}=34)$ or six $(\mathrm{N}=5)$. The other variable is the number of times an interviewee changed her or his profession (never, once, twice or more).

[Table 1 near here]

Descriptive statistics for self-employed and others are given in table 1. The proportion on men is higher among self-employed than among paid employees, and self-employed are on average four years older. More important for the topic of this note is that on average self-employed have more kinds of professional training, and changed their profession more often.

number of the study is 3379. Interested researchers should contact Horst Weinen (Email: weinen@za.uni-koeln.de). To facilitate replication and extensions the STATA do-files used to produce the results reported in this note are available from the author on request. 


\section{Testing the jack-of-all-trades view}

The empirical model applied in the econometric investigation mimics Lazear's approach to test his jack-of-all-trades view. The dummy variable indicating whether an individual is self-employed or not is regressed on a set of control variables (sex, nationality, and age), the number of different kinds of professional training, and the dummy variables indicating whether the interviewee did change the profession once, or at least twice, respectively, using those who never changed the profession as the reference group. Probit estimates are reported in table 2 in the column headed 'Model A', while 'Model B' adds quadratic terms of age and number of different kinds of professional training to control for non-linearity.

[Table 2 near here]

Given that the quadratic terms added in model B are highly significant statistically we will focus on the results reported in the last column of table 2 . To start with the control variables the probability of being self-employed is higher for men and foreigners, and it is increasing with age at a decreasing rate (note that the estimated maximum of the quadratic relationship between age and the probability of being selfemployed is reached at the age of 65.685 years that is out of the range covered in the sub-sample used here).

As regards the number of different kinds of professional training the estimated coefficients point to an inversely u-shaped relationship with the probability of being self-employed. The estimated maximum of this function, however, lies at 3.96 kinds, and given the distribution of the number of kinds in our sample described above (with nearly no observations for five or six kinds of professional training) we have evidence that the probability of being self-employed increases with the number of different kinds of professional training at a decreasing rate. Furthermore, this probability is higher for individuals that changed their profession - the estimated coefficients of both dummy 
variables are positive and statistically significant at a usual level. These empirical results support the jack-of-all-trades view of entrepreneurship put forward by Lazear (2002).

Discussion of the results hitherto was limited to the statistical significance of the estimated coefficients and the direction of influence conducted by the variables. Information on the extent of this influence, or on the economic significance, however, is even more important. Evidently, a variable that has no statistically significant impact can be ignored from an economic point of view, but the opposite is not true: A variable that is highly significant statistically might not matter at all economically - if the estimated probability for being self-employed increases by 0.00001 percentage points when an individual has four kinds of professional training instead of none the number of kinds of professional training can be ignored in the discussion of reasons for becoming an entrepreneur irrespective of any high level of statistical significance indicated by the prob-value.

Unfortunately, the estimated coefficients from the probit model can not easily be used for statements about the size of the ceteris paribus effect of a change of the value of an exogenous variable on the probability of being self-employed, because the size of this effect depends on both the value of the exogenous variable under consideration and on the values of all other variables in the model. A way to ease interpretation of the results is to compute the estimated probability of being self-employed for (hypothetical) individuals with different combinations of values of those exogenous variables that are at the center of interest. We follow this strategy: Based on the results reported for model B in table 2 we consider a 40 years old German male and compute the estimated probability for different combinations of the number of kinds of professional training and the number of changes of professions. Results of this exercise are reported in table 3.

[Table 3 near here] 
The estimated probabilities for being self-employed clearly demonstrate that both the number of different kinds of professional training and the number of changes of professions do matter economically. To illustrate this, having one more kind of professional training increases the probability of being self-employed by more than three percentage points if the same person has one instead of zero, or two instead of one, and given that the percentage of self-employed in the sample in 9.34 percent this indicates a high impact of this variable. The impact of the number of changes of the profession is somewhat smaller, but still significant in an economic sense.

\section{Concluding remarks}

A theory that holds for graduates from a U.S. top university and for the German working population as a whole surely is a candidate for the box of tools economists use to investigate entrepreneurship. Further empirical tests with other data sets from other countries and time periods will help to decide whether it can be considered a swiss army knife in this field.

\section{References}

Lazear, Edward P., 2002, Entrepreneurship, National Bureau of Economic Research Working Paper 9109, August. 
Mean Std. Dev.

Sex (Dummy; 1 = Male)

German (Dummy; 1 = Yes)

Age (Years)

Number of different kinds of professional training

Number of changes of profession: One (Dummy; $1=$ Yes)

Number of changes of profession: Two or more (Dummy; 1 = Yes)

Number of cases
Self-employed

Others

\begin{tabular}{rrrr}
0.67 & 0.47 & 0.55 & 0.50 \\
0.96 & 0.19 & 0.96 & 0.20 \\
44.07 & 10.16 & 40.09 & 10.69 \\
1.45 & 0.77 & 1.24 & 0.71 \\
0.31 & 0.46 & 0.24 & 0.43 \\
0.12 & 0.32 & 0.09 & 0.29 \\
\multicolumn{2}{c}{3148} & \multicolumn{2}{c}{30485}
\end{tabular}


Table 2: Probit estimates for being self-employed

\begin{tabular}{rr} 
Model A & Model B \\
0.221 & 0.222 \\
0.000 & 0.000 \\
-0.092 & -0.121 \\
0.070 & 0.018 \\
0.016 & 0.048 \\
0.000 & 0.000 \\
& $-3.66 \mathrm{e}-4$ \\
0.156 & 0.000 \\
0.000 & 0.271 \\
& 0.000 \\
0.130 & 0.034 \\
0.000 & 0.001 \\
0.077 & 0.000 \\
0.020 & 0.077 \\
-2.303 & 0.019 \\
0.000 & -2.988 \\
& 0.000 \\
33663 & 33663 \\
\hline
\end{tabular}


Table 3 Estimated probability for being self-employed ${ }^{1}$

Number of different kinds of professional training

$\begin{array}{lllll}\text { Zero } & \text { One } & \text { Two } & \text { Three } & \text { Four } \\ & & & & \\ 0.060 & 0.094 & 0.126 & 0.148 & 0.155 \\ 0.076 & 0.116 & 0.153 & 0.177 & 0.186 \\ 0.070 & 0.108 & 0.143 & 0.166 & 0.174\end{array}$

${ }^{1}$ The estimates are based on the results reported for model B in table 2 for a 40 years old German male. 


\section{IZA Discussion Papers}

\begin{tabular}{|c|c|c|c|c|}
\hline No. & Author(s) & Title & Area & Date \\
\hline 577 & $\begin{array}{l}\text { K. Ariga } \\
\text { G. Brunello }\end{array}$ & $\begin{array}{l}\text { Are the More Educated Receiving More } \\
\text { Training? Evidence from Thailand }\end{array}$ & 2 & $09 / 02$ \\
\hline 578 & $\begin{array}{l}\text { I. N. Gang } \\
\text { F. L. Rivera-Batiz } \\
\text { M.-S. Yun }\end{array}$ & $\begin{array}{l}\text { Economic Strain, Ethnic Concentration and } \\
\text { Attitudes Towards Foreigners in the European } \\
\text { Union }\end{array}$ & 1 & $09 / 02$ \\
\hline 579 & $\begin{array}{l}\text { I. N. Gang } \\
\text { M.-S. Yun }\end{array}$ & $\begin{array}{l}\text { Decomposing Inequality Change in East } \\
\text { Germany During Transition }\end{array}$ & 4 & $09 / 02$ \\
\hline 580 & $\begin{array}{l}\text { I. N. Gang } \\
\text { J. Landon-Lane } \\
\text { M.-S. Yun }\end{array}$ & $\begin{array}{l}\text { Gender Differences in German Upward Income } \\
\text { Mobility }\end{array}$ & 1 & $09 / 02$ \\
\hline 581 & $\begin{array}{l}\text { P. Cahuc } \\
\text { F. Malherbet }\end{array}$ & $\begin{array}{l}\text { Unemployment Compensation Finance and } \\
\text { Labor Market Rigidity }\end{array}$ & 5 & $09 / 02$ \\
\hline 582 & $\begin{array}{l}\text { P. Cahuc } \\
\text { C. Gianella } \\
\text { D. Goux } \\
\text { A. Zylberberg }\end{array}$ & $\begin{array}{l}\text { Equalizing Wage Differences and Bargaining } \\
\text { Power: Evidence from a Panel of French Firms }\end{array}$ & 6 & 09/02 \\
\hline 583 & $\begin{array}{l}\text { P. Cahuc } \\
\text { F. Fontaine }\end{array}$ & $\begin{array}{l}\text { On the Efficiency of Job Search with Social } \\
\text { Networks }\end{array}$ & 5 & 09/02 \\
\hline 584 & $\begin{array}{l}\text { C. J. Heinrich } \\
\text { P. R. Mueser } \\
\text { K. R. Troske }\end{array}$ & $\begin{array}{l}\text { Welfare to Temporary Work: Implications for } \\
\text { Labor Market Outcomes }\end{array}$ & 3 & $09 / 02$ \\
\hline 585 & $\begin{array}{l}\text { M. Cervellati } \\
\text { U. Sunde }\end{array}$ & $\begin{array}{l}\text { Human Capital Formation, Life Expectancy and } \\
\text { the Process of Economic Development }\end{array}$ & 3 & $09 / 02$ \\
\hline 586 & $\begin{array}{l}\text { P. Díaz-Vázquez } \\
\text { D. Snower }\end{array}$ & $\begin{array}{l}\text { On-the Job Training and the Effects of Insider } \\
\text { Power }\end{array}$ & 3 & 09/02 \\
\hline 587 & $\begin{array}{l}\text { H. Bonin } \\
\text { W. Kempe } \\
\text { H. Schneider }\end{array}$ & $\begin{array}{l}\text { Kombilohn oder Workfare? Zur Wirksamkeit } \\
\text { zweier arbeitsmarktpolitischer Strategien }\end{array}$ & 3 & 09/02 \\
\hline 588 & M. Frölich & $\begin{array}{l}\text { Nonparametric IV Estimation of Local Average } \\
\text { Treatment Effects with Covariates }\end{array}$ & 6 & $09 / 02$ \\
\hline 589 & $\begin{array}{l}\text { S. Jurajda } \\
\text { K. Terrell }\end{array}$ & $\begin{array}{l}\text { Job Growth in Early Transition: Comparing Two } \\
\text { Paths }\end{array}$ & 4 & 09/02 \\
\hline 590 & $\begin{array}{l}\text { H. Görg } \\
\text { E. Strobl } \\
\text { F. Walsh }\end{array}$ & $\begin{array}{l}\text { Why Do Foreign-Owned Firms Pay More? } \\
\text { The Role of On-the-Job Training }\end{array}$ & 2 & $10 / 02$ \\
\hline 591 & $\begin{array}{l}\text { H. Görg } \\
\text { E. Strobl }\end{array}$ & $\begin{array}{l}\text { Spillovers From Foreign Firms Through Worker } \\
\text { Mobility: An Empirical Investigation }\end{array}$ & 1 & $10 / 02$ \\
\hline 592 & J. Wagner & $\begin{array}{l}\text { Testing Lazear's Jack-of-All-Trades View of } \\
\text { Entrepreneurship with German Micro Data }\end{array}$ & 5 & $10 / 02$ \\
\hline
\end{tabular}

